Citation: Yaşar E. \& Ulusoy T. (2019), Industry 4.0 And Turkey, BMIJ, (2019), 7(1): $24-41$ doi: http://dx.doi.org/10.15295/bmij.v7i1.1038

\title{
INDUSTRY 4.0 and TURKEY
}

Esra YAŞAR $^{1}$

Tuba ULUSOY2
Received (Başvuru Tarihi): 27/12/2018

Accepted (Kabul Tarihi): 25/02/2019

Published Date (Yayın Tarihi): 25/03/2019

\section{ABSTRACT}

In 2011, Germany kicked off the Fourth Industrial Revolution (Industry 4.0) to empower its economy. Since then, revolutionary changes have been implemented all over the world, increasing international competition. Smart-factory capabilities emerging from Industry 4.0 have many benefits such as lowering production costs of existing factories and increasing product quality. However, with such revolutionary changes, an orientation period is required for any implementer. To efficiently manage such an orientation period, the extant situation must first be analyzed. Only then should the necessary changes and innovations be applied. In this study, Turkey's Industry 4.0 adoption opportunities are evaluated by using a survey technique that analyzes extant situations and potential results.

Keywords: Turkey, Industry 4.0, Society

JEL Codes: L00, O10, O30, 033

\section{ENDÜSTRİ 4.0 ve TÜRKIYYE}

\section{$\ddot{O} Z$}

2011 yılında Almanya'nın ekonomisini güçlendirmek adına başlatmış olduğu Endüstri 4.0-Sanayi 4.0Dördüncü Sanayi Devrimi projesi bütün dünyada uygulanmaya başlanmış ve ülkelerin birbirleri ile rekabetini artırmış durumdadır. Endüstri 4.0 ile gelen akıll fabrika teriminin mevcut fabrikaların üretim maliyetini düşürmek, ürün kalitesini artırmak gibi pek çok faydası bulunmaktadır. Bu yüzden hem şirketlerin, hem de ülkelerin dikkatini çeken bu projeye ilgili kişiler ve/veya birimler tarafindan uyum süreci başlatılmış durumdadır. Uyum sürecinin verimli bir şekilde yönetilebilmesi için öncelikle mevcut durum analiz edilmeli, sonrasinda ise gerekli değişiklikler/yenilikler uygulanmalıdır. Bu çalışmada ise Endüstri 4.0 projesi Türkiye özelinde değerlendirmeye alınmış, mevcut durumun analiz edilmesi için bir anket çalışması yapılmış ve sonuçlar sunulmuştur.

Anahtar Kelimeler: Türkiye, Endüstri 4.0, Toplum

JEL Kodu: L00, O10, O30, 033

\footnotetext{
${ }^{1}$ Araştırma Görevlisi, KTO Karatay University, esrayasaarr@gmail.com

${ }^{2}$ Araştırma Görevlisi, Necmettin Erbakan University, ulusoytuba@ gmail.com
} 


\section{INTRODUCTION}

Driven by economics, worldwide industries manufacture products with the help of mechanical and automatic systems. Consequently, the changes to these production technologies over time have triggered industrial revolutions (Lasi et al., 2014). Whereas revolutions of this nature often result in significant job loss, they also result in processes that influence international economies, thus creating global impact on the world's population.

The invention and application of the steam engine in the 18th century marks the 1st Industrial Revolution. Electric power and mass production mark the 2nd Industrial Revolution. Information technologies and electronic systems have marked the 3rd Industrial Revolution, beginning in the 1970s (Bauer et al., 2014).

The beginning of the 4th Industrial Revolution (Industry 4.0) has hinged on the development and application of machines equipped with sensors and intelligent control units, enabling them to communicate with one another and provide automatic troubleshooting and reporting (Lukac, 2015). Brynjolfsson and McAfee referred to this age as "The Second Machine Age" in their book, published in 2014. The authors noted that the first machine age began in the 1700's with the invention of the steam engine and that we are now moving into the second age because of our exponential digital and integrated technological developments (Brynjolfsson, Mcafee, 2014).

Over the last two decades, the European economy has encountered many problems, such as an aging population and competition with developing countries. According to the Economic Policy Committee and European Commission, by 2050, the working age population will have been reduced by approximately 48 million (16\%). However, there will still be 58 million elderly people to take care of (Hewitt, 2002). As of 2011, developing countries, such as China, India, and Brazil, have increased their industrial value by $179 \%$ (compared to 1990), whereas western European countries have seen a $36 \%$ decrease in their industrial value. It is predicted that Industry 4.0 will solve these problems through the reduction of the workforce, the shortening of the product development process, and by improving efficient resource use (Quin et al, 2016). One causal factor of Industry 4.0 is the drive of European economies to become successful against their competition (i.e., developing countries). Furthermore, their inclination to tackle significant industrial and social problems via technological means has resulted in even more advances. 
"Industry 4.0" was coined at the Hannover Fair in Germany. (Lee, 2013) Germany led the way; then, other countries followed, attempting to diversify or improve the concept. In 2013, Industry 4.0 was defined in a report published by the German National Academy of Sciences and Engineering as a strategic vision. The main theme of the World Economic Forum, held in Davos in 2016, was Industry 4.0. Thus, the term has since attracted the attention of the entire industrial world (Pfeiffer, 2017).

Whereas Industry 4.0 technologies tend to reduce labor-intensive production while simultaneously reducing the attractiveness of cheap labor, they have provided a competitive advantage to countries that have adopted them (Özkan et al.2018).

Predictably, there are clear socio-economical differences among countries, according to their levels of adaptation. The Boston Consulting Group (BCG) and Pricewaterhouse Coopers $(\mathrm{PwC})$ have studied this phenomenon to evaluate the stages of Industry 4.0 among different countries. In 2016, BCG surveyed more than 600 German and American companies, aiming to identify the challenges faced when implementing Industry 4.0 and their degrees of compliance. The results showed that American and German companies were nearly at the same level of Industry 4.0 application, but that German companies were more ambitious. Companies in both countries have stated that the biggest challenges in implementing Industry 4.0 technologies are the availability of qualified personnel, data security, and heavy investment requirements (Lorenz et al., 2016).

In 2016, PwC conducted a survey of more than 2,000 participants from nine major industries in 26 countries, including the United States, Canada, United Kingdom, Germany, France, Brazil, Spain, China, and Japan. According to the results, 33\% of the companies surveyed had reached advanced levels of technology, whereas $72 \%$ aimed to reach their targets by 2020 .

It is inevitable that Industry 4.0 will impact societies. Thus, to integrate it well, we should seek ways to also solve environmental and demographic problems. Japan calls this the "Society 5.0" philosophy. At the 2017 Center of Office Automation and Information Technology and Telecommunication (CeBIT fair) in Germany, the Japanese prime minister introduced Society 5.0 to the World (Pîrvu, Zamfirescu, 2017).

Among the aims of Society 5.0, technological transformations should be leveraged to benefit society, to make us smarter, to enable women, children, and the elderly to remain active 
participants, to improve safety in both the cyber and real worlds, and to find solutions to global problems.

As stated in the CeBIT report, "it is necessary to cope with obstacles when striving to hit the targets of Society 5.0." Therefore, nations should consider adopting the following policies and objectives.

- Develop national strategies for Society 5.0 with the participation of academia and industry

- Add appropriate statutes to the legal systems

- Create a social consensus

- Facilitate academia, government, and industry to examine ethical, legal, and social factors while using the techniques for humanities and social sciences

- Reform education with the participation of all citizens

- Promote cybersecurity, artificial intelligence technologies, robots, nanotechnology, and biotechnology

- Train specialists in the field

Figure 1 shows the changes of societal structure from the birth of the first human being to the era of Society 5.0.

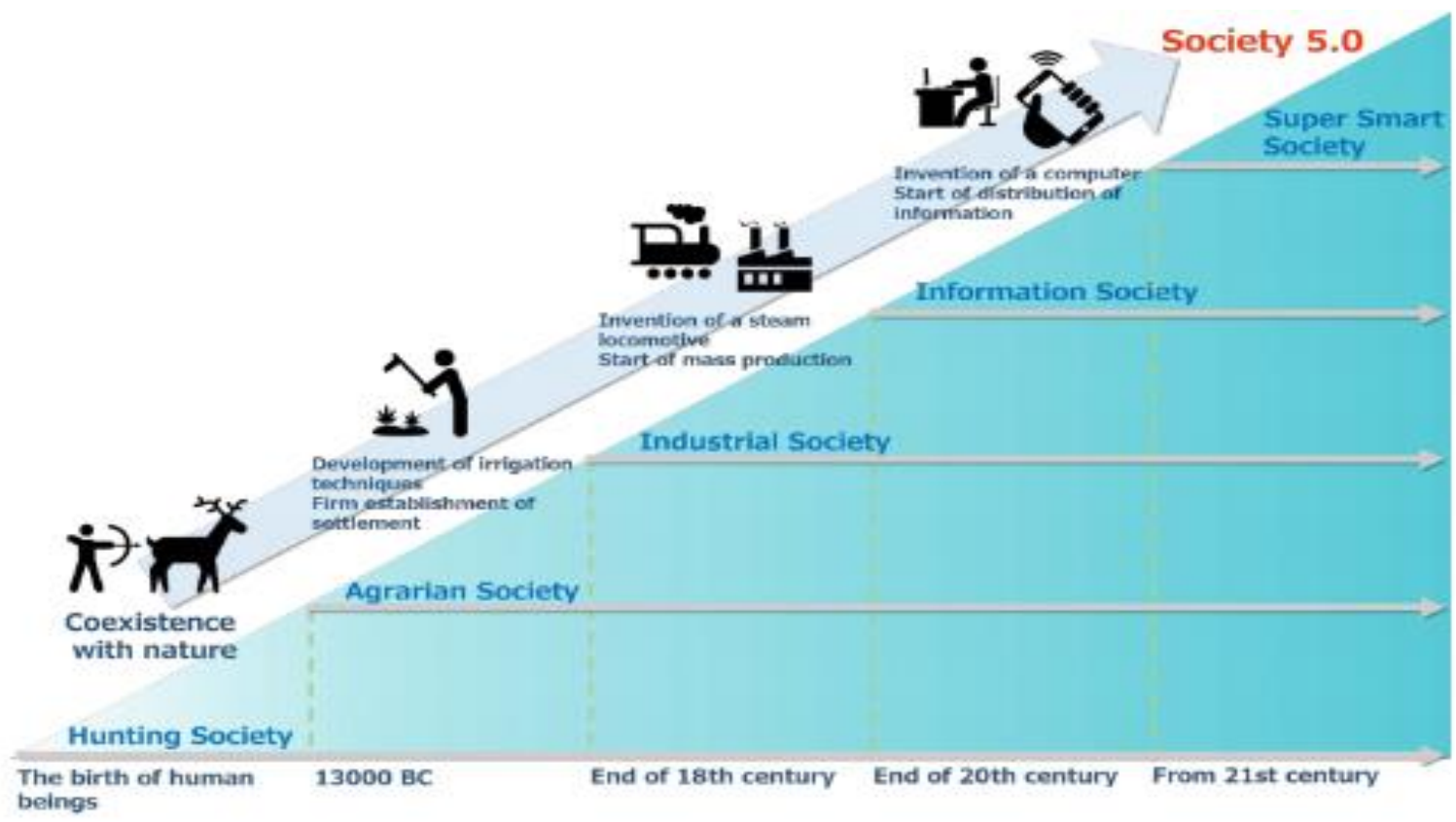

Figure 1: Societal Structure from the Birth of the First Human Being to the Era of Society 5.0 (Keidanren, 2016)

As seen in Figure 1, societies have always been influenced by industrial developments. 
The social structure emerging from hunter-gatherer societies eventually gave way to agrarian economies. With agriculture came irrigation, which led to more sedentary lifestyles. Eventually, the steam engine changed everything, and society became wholly industrial. Later, the information period began. Now, Industry 4.0 has again changed the social order; the era of intelligent society has begun. Thus, the maximization of public prosperity has become the goal of many countries.

This study aims to determine the stage at which firms operating in Turkey fall in the Industry-4.0 adaptation process. The results of a survey are provided in Section 5. In Section 2, however, concepts and information on Industry 4.0 technologies are given. In Section 3, a literature review is provided. Section 4 provides results of the studies in Turkey. Finally, this paper concludes with Section 6.

\section{INDUSTRY 4.0 and BASIC CONCEPTS}

In this section, we elaborate on the concepts we often hear about Industry 4.0.

Cyber-Physical Systems are a new generation of technologies in which physical objects and information systems are integrated. For example, among many computing, communications, and control advancements, cyber-physical systems allow prosthetic human limbs to be controlled by brain signals (Baheti and Gill, 2011). Production tools can communicate with each other and provide instantaneous data collection and analysis. The American National Academy of Engineering has identified 14 areas related to environmental, health, and social issues that could benefit from cyber-physical systems, including areas such as biomedical and health systems, next-generation air transport systems, smart grids, and renewable energy (Baheti and Gill, 2011).

The Internet of Things is a global infrastructure that enables advanced services by linking physical and virtual objects based on existing and developing interoperable information and communication technologies, according to the International Telecommunication Union. Data can be transferred over WiFi, for example, without human intervention, to make life easier for everyone while helping to bridge the gap between virtual and physical worlds (Mattern and Floerkemeier, 2010).

Cloud Computing is a technology that provides optional network access according to a pool of configurable computing resources that can be achieved quickly with minimal management effort or service-provider interaction, according to the National Institute of Standards and Technology. The cloud model has been revived from earlier technological 
models, rebuilt for a more ubiquitous instantiation of internet storage and workspace (Zhang et al., 2010). When companies use cloud computing technologies, they enjoy many advantages, such as fewer personnel, lower energy costs, and instant access to data (Seyrek, 2011). Simultaneously, this technology is flexible, allowing both providers and users to operate and update from any place having internet access (Henkoğlu and Külcü, 2013).

Augmented Reality is an expanding technology implemented to integrate computer resources with human vision, placing virtual objects into the real world (Billinghurst et al., 2015). It also enriches the human experience, whether at work or at play. Whereas extant applications use computers and simulators, retinal imagers and holograms are just around the corner. Soon, augmented reality technology is expected to become a part of everyday life (Altınpulluk and Kesim, 2015).

Big Data is a technological and architectural method of handling, storing, and operating on highly variable, high-volume datasets by providing high-speed data acquisition, discovery, and analysis (Gantz and Reinsel, 2011). Big data not only motivates people to use technology, it also has the potential to change their thinking and perceptions (Doğan and Arslantekin, 2016). The importance of big data continues to grow, both academically and practically (Özköse et al., 2015). Many companies and government enterprises benefit from big data's analytical power. Moreover, big data provides new levels of predictability, in which even human behaviors can be foreseen and accommodated.

Cybersecurity focuses on information security, privacy, data integrity, and availability in information systems (Bishop, 2005). Production systems suffered significant gaps in security, even before the emergence of Industry 4.0. Thus, cybersecurity has long been an area of critical importance (Wegner et al., 2017). As data has evolved, so have the security requirements.

Autonomous Robots leverage artificial intelligence to make decisions about a particular job. Robots are very helpful in situations that may be dangerous to humans. In Industry 4.0, they are very common indeed. Autonomous robots are an important asset for adapting and managing Industry 4.0 enterprises (Richert et al., 2016).

Additive Manufacturing includes 3-D printing, which is used to combine layers of material into a functional object. With this technology, production times can be greatly reduced and strongly managed (Conner et al., 2014). This allows savings in raw materials, storage, purchasing, and logistics (Öksüz et al. 2017). 
Simulation turns data into a model physical system, in which the virtual world can be manipulated and tested for consequences (Landriscina, 2013). Simulation technology is indispensable to many fields (Çelen, 2017). Products, services, and systems can be tested before they are produced, thus optimizing features while eliminating defects.

\section{LITERATURE REVIEW}

The first study on the concept of Industry 4.0 was performed by Kagermann and several colleagues, in which the authors shared the general framework of Industry 4.0 as it related to the internet revolution (Kagermann et al., 2011). Many studies have since been conducted; some of which are summarized below. However, the scope of this study is to investigate the impact of Industry 4.0 on Turkey.

In their work entitled "Smartphone Green Vision at Dawn of Industry 4.0," Hofmann et al. discussed green vision (e.g., sustainable production) as an important part of Industry 4.0, noting that smartphones should have a fundamental impact not only on machine vision but also on science and education in related fields (Hofmann et al., 2012).

In a 2014 study, Anderl explained the concepts of cyber-physical systems, the internet of things, information carrier components, security, privacy, information protection, and expected Industry 4.0 benefits (Anderl, 2014).

In a study conducted by Herman et al. in 2016, design principles of Industry 4.0 were described by conducting a quantitative text analysis and a qualitative literature research (Hermann et al., 2016).

In 2016, Stock and Seliger defined Industry 4.0 in micro and macro terms using existing findings, providing a comprehensive understanding by evaluating different opportunities for sustainable production. Additionally, they discussed the use of machines to empower sustainable production (Stock and Seliger, 2016).

In 2018, Perales and colleagues provided a general definition and classification of concepts and technologies. These classes were based on the characteristics of Industry 4.0 and the technologies that support it (Perales et al., 2018).

Twenty "Industry 4.0" publications regarding Turkey were identified by the present report (September 3, 2018, Web of Science data). In these studies, the general scope of Industry 4.0 and Turkey's status were discussed, focusing on the economic impacts. Yavuz, Özkan and $\mathrm{Al}$ (2018) studied the global impact of Industry 4.0, focusing on the impacts in Turkey. Owing 
to developing technologies resulting from Industry 4.0, the cheap labor force would soon be eliminated, constituting an employment crisis in Turkey. Moreover, the effects of a new era of foreign trade were discussed, suggesting that the logistics sector should be updated in light of the opportunities and risks. They also discussed the possible advantages for Turkey, provided the country takes the necessary steps to integrate Industry 4.0. Turkey is a low-labor-cost country, owing to its highly competitive location. Furthermore, there is a large young population compared to other countries, and Industry 4.0 will decrease the need for unskilled labor.

In some studies, summarized below, the relationship between Industry 4.0 and education was explained. In others, suggestions were made about innovations in education.

For universities to develop a structure capable of managing this new era, Aybek (2017) emphasized that national, international, and local government studies of Industry 4.0 are among the most contentious in higher education. He then presented details of his concept of “University 4.0." In this approach, innovative management and leadership, lifelong learning, and support services are considered key elements, whereas funding, return on investment, and quality assurance provide feedback among these components.

Öztemel used the term "Education 4.0," arguing that transformation required a more innovation-oriented structure, because all areas of society would be affected. Furthermore, education would be crucial to its development. Using regression, Education 1.0 becomes the educational system of an agrarian society. Education 2.0 becomes the system in an industrial society. Education 3.0 becomes the education system shaped according to the needs of an information society. Thus, Education 4.0 becomes the system developing alongside Industry 4.0 supporting lifelong learning (Öztemel, 2017).

In "Industry 4.0 and Simulation," Çelen suggested that students should be provided professional and technical information to establish the smart factories of the future, to develop a simulation-supported education in accordance with Industry 4.0, and to open simulation-based multi-disciplinary departments (Çelen, 2017).

Sener and Elevli stressed that Turkey has a significant advantage with Industry 4.0, because of its average population age of 29. To combat unemployment, it will be necessary for governments, free-market players, academia, and the public to fully cooperate. They also proposed an academy that features programming, software design, hardware, data mining, networking, cryptography, cybersecurity, artificial intelligence, computer-aided design, 
computer-aided engineering, 3-D printing, system design, analysis, brand value, and marketing.

With such an academy, the authors suggested it would be possible to prevent massive unemployment when integrating Industry 4.0 (Sener and Elevli, 2017).

Demir (2018) echoed Sener's and Elevli's sentements, stating that the concept of Education 4.0 was essential to meet the needs of the developing age. He emphasized that this new system should provide people with thinking skills and continuous learning, and that new learning models should be developed, representing a holistic approach commiserate with Industry 4.0 (Demir, 2018).

Some studies debated whether Industry 4.0 would be a threat or an opportunity for Turkey. Those threats and opportunities are summarized below.

\section{Threats}

- Inability to use the new technology owing to lack of facilities for small businesses (Nuroğlu, 2018).

- Inability to use the technology because of failure to provide adequate training (Nuroğlu, 2018).

- Because internet-based technologies will be used, devices will be connected to the internet, increasing risk of cyber-attack (Ünver, Özbilgin, 2018).

- Technological unemployment caused by robots (Koca, 2018).

- Increased demand for a high-quality workforce, increasing risk of brain-drain (Koca, 2018).

- Legal problems related to the new processes.

\section{Opportunities}

- Economic transformation, leveraging medium- and high-tech production for valueadded, knowledge-based transactions (Genç, 2018).

- Timely production with the additive manufacturing technologies (Soylu, 2018).

- A young population.

- Access to new domestic and foreign markets.

- Virtual/simulated product and service testing. 
- Faster and better quality access to customers with instantaneous data analysis.

- Emergence of new job opportunities.

Governmental incentives, such as income- and corporate-tax exemption or rent allowances will be very beneficial to research and development and societal integration (Genç, 2018).

\section{DEVELOPMENTS IN TURKEY REGARDING INDUSTRY 4.0}

Higher education should build a workforce that meets the needs of Industry 4.0. Studies should focus not only on higher education, but also on vocation training. In Turkey, various studies have been conducted.

Coşkun et al. emphasized that higher education should be adapted to Industry 4.0 and provided examples from the engineering education curriculum, laboratories, and social activities at the Turkish-German University in Istanbul (Coşkun et al., 2017).

An online Industry 4.0 platform (www.endustri40.com) was established by Elektrikport with other companies and associations operating in Turkey, sponsored primarily by Siemens. The vision was "Being a Pioneer in the Digital Transformation of Turkish Industry" with a mission of "To provide an impartial and reliable guide to the digital transformation of Turkish Industry and to be the platform where all small, medium, and large industrial organizations meet, learn, and share." The site aims to help spread Industry-4.0 consciousness.

The Turkish Industry \& Business Association (TÜSİAD) also studied Industry 4.0. A workgroup was established within TÜSİAD, in cooperation with public and private sectors. Their objectives included assessing measures needed for the implementation of Industry 4.0 in Turkey and evaluating the industry's potential costs and benefits. A report, prepared by TÜSİAD and BCG, entitled "Turkey’s Digital Transformation Capabilities in Industry," analyzed the current situation in terms of production and technology in Turkey to create a roadmap for the future. From this report, duties of the government were promulgated: provide necessary training to companies; provide consultancy; provide adequate incentives; develop comprehensive human resources for a qualified workforce; and make necessary legal provisions. The duties of the public and private sectors and academia included making necessary investments in companies that will produce the technology, establishing high-tech institutions, increasing university-industry cooperation, and supporting the supplier ecosystem within the framework of the technologies created. 
Another study on the subject, "CEO Perspective to Digital Change in Turkey," was conducted by TÜSİAD, reporting the results of interviewing senior executives from 58 companies. A general evaluation was conducted by inquiring about the digital changes faced by the executives. Reportedly, the companies were all aware of the necessity of digital transformation and they held that they must integrate digital work into their normal processes. The report also stated that there the transformation process would be a long haul. However, this is the purpose of a roadmap. Thus, Turkey may indeed achieve the desired end state.

In 2017, an international symposium, entitled "International Symposium on Industry 4.0 and Applications," was organized by Karabük and Perlis Universities of Malaysia. During the consecutive symposium in 2018, Anadolu University led the Operations Research Industrial Engineering National Congress with "Operations Research Industrial Engineering and the 4th Industrial Revolution." The aim of such a symposium is to draw attention to the subject of Industry 4.0 and to inspire studies on this subject.

To benefit from Industry 4.0, the digitalization of a single firm is insufficient. Other companies in the same field must also adapt to facilitate the requisite level of smart-system utilization. Additionally, small and medium-sized enterprises (SME) that may otherwise would face difficulties adapting Industry 4.0 standards must be supported by governments and large companies (Nuroglu, 2018).

While Industry 4.0 is perceived as a threat to labor-intensive countries, with the right steps, it can become an opportunity. This is the case for Turkey, who should use this opportunity to follow the roadmap and shortly become ranked among the world's top 10 economies (Nuroglu, 2018).

\section{SURVEY RESULTS}

Questionnaires comprising eight questions were delivered to more than 100 companies of varying sizes in different sectors in Turkey; however, only 33 responses were received. The questions and their answer distributions are given in the charts below. Additional data were taken from survey results obtained by PwC and BCG in 2016.

While 17 of the companies were SMEs, 16 were large enterprises with more than 250 employees. These companies operated in different sectors, such as automotive, information technology, food, transportation and logistics, electronics, home appliances, education, and consultancy. 
1) Does your company know Industry 4.0 technologies?

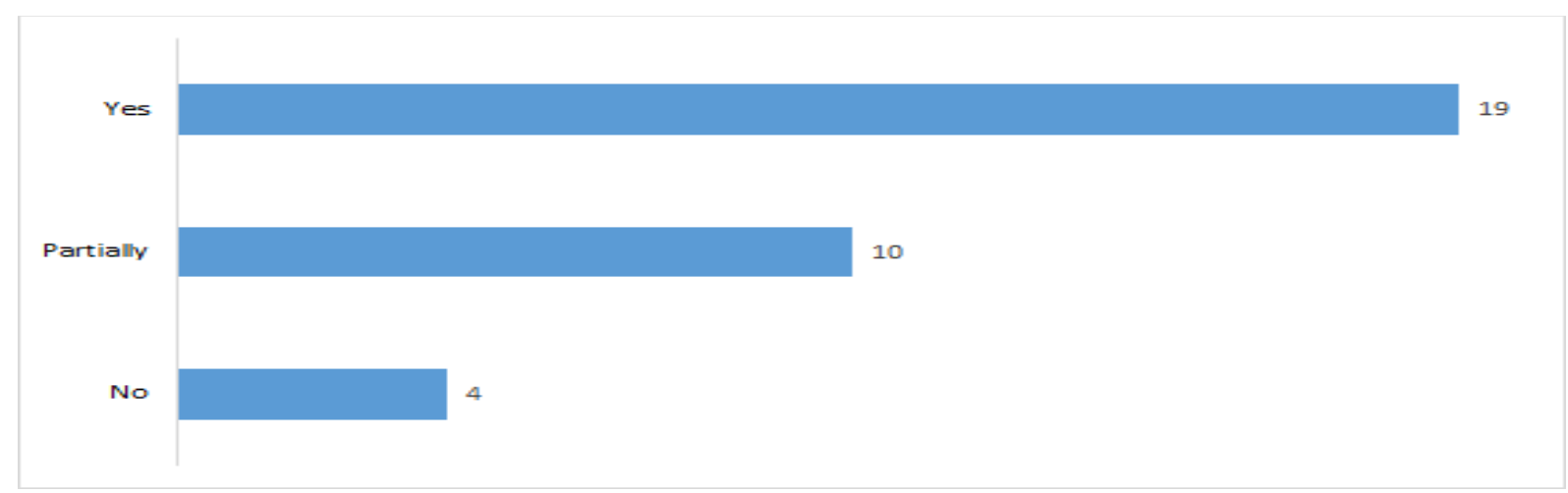

Figure 2: Split of The Responses of The First Question

More than $50 \%$ of the surveyed companies stated that they had information about Industry 4.0. Only four firms had no knowledge.

2) Is your company ready for Industry 4.0 technologies? (Lorenz et al., 2016)

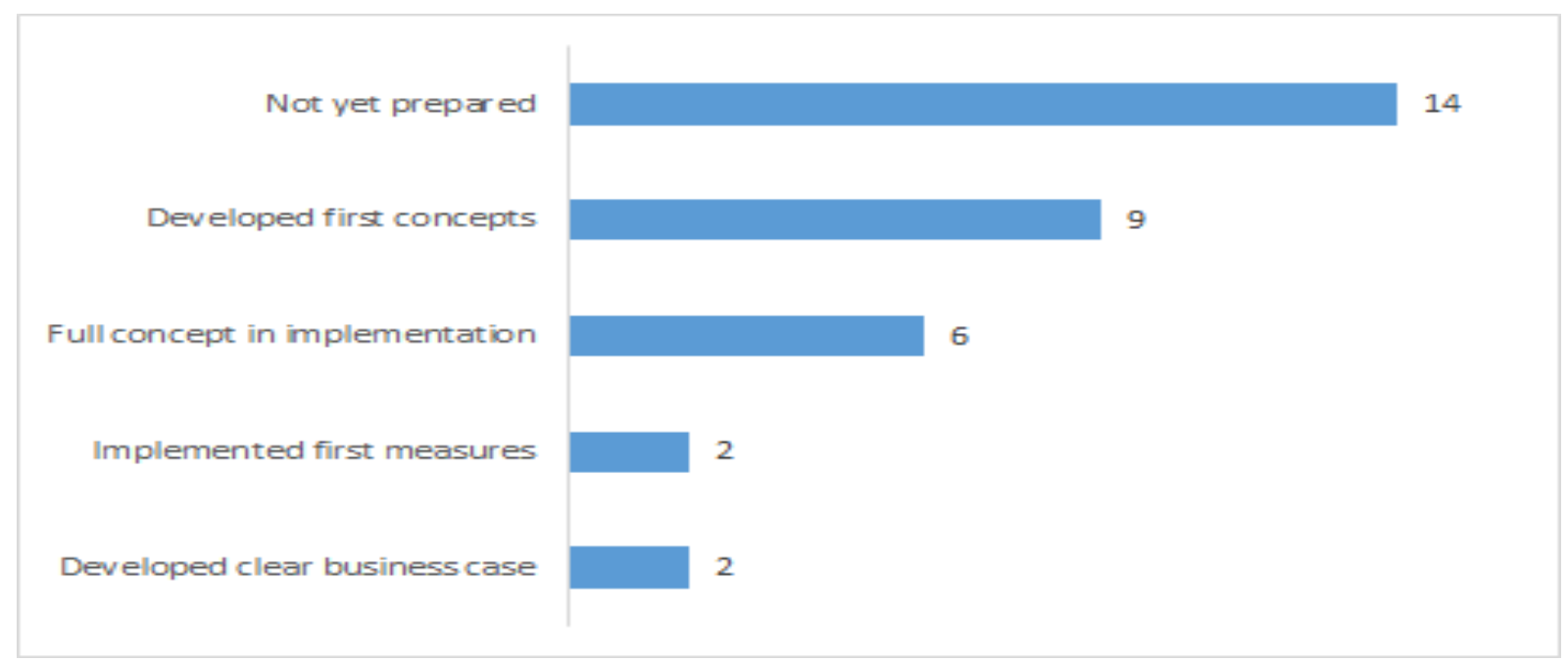

Figure 3: Split of The Responses of The Second Question

While $42 \%$ of the firms had not made any preparations, $27 \%$ had developed the first concepts. 
3) Which of the following applications is used by your company? (Lorenz et al., 2016)

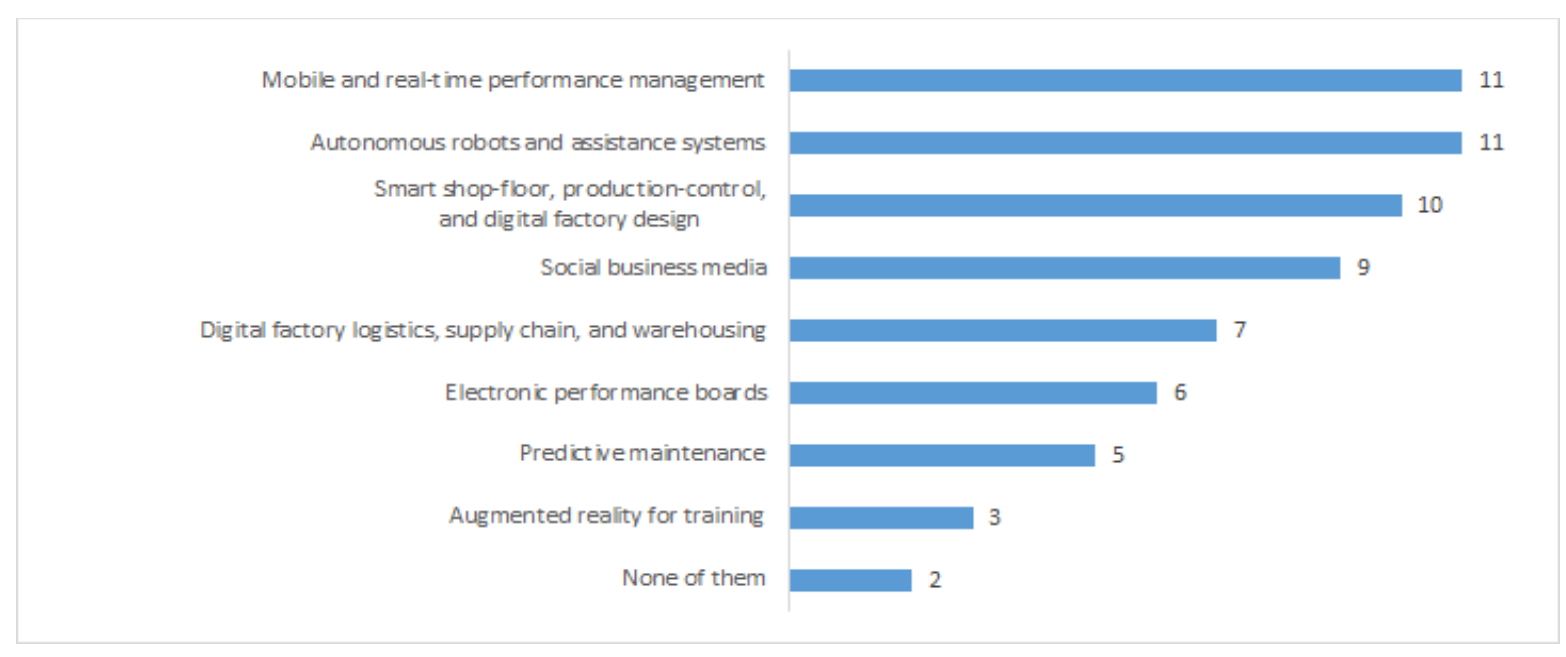

Figure 4: Split of The Responses of The Third Question

Firms reported that automatic robots and assistance systems, as well as mobile and realtime performance management applications were preferred.

4) What qualities would you expect your employees to have in the future? (Lorenz et al., 2016)

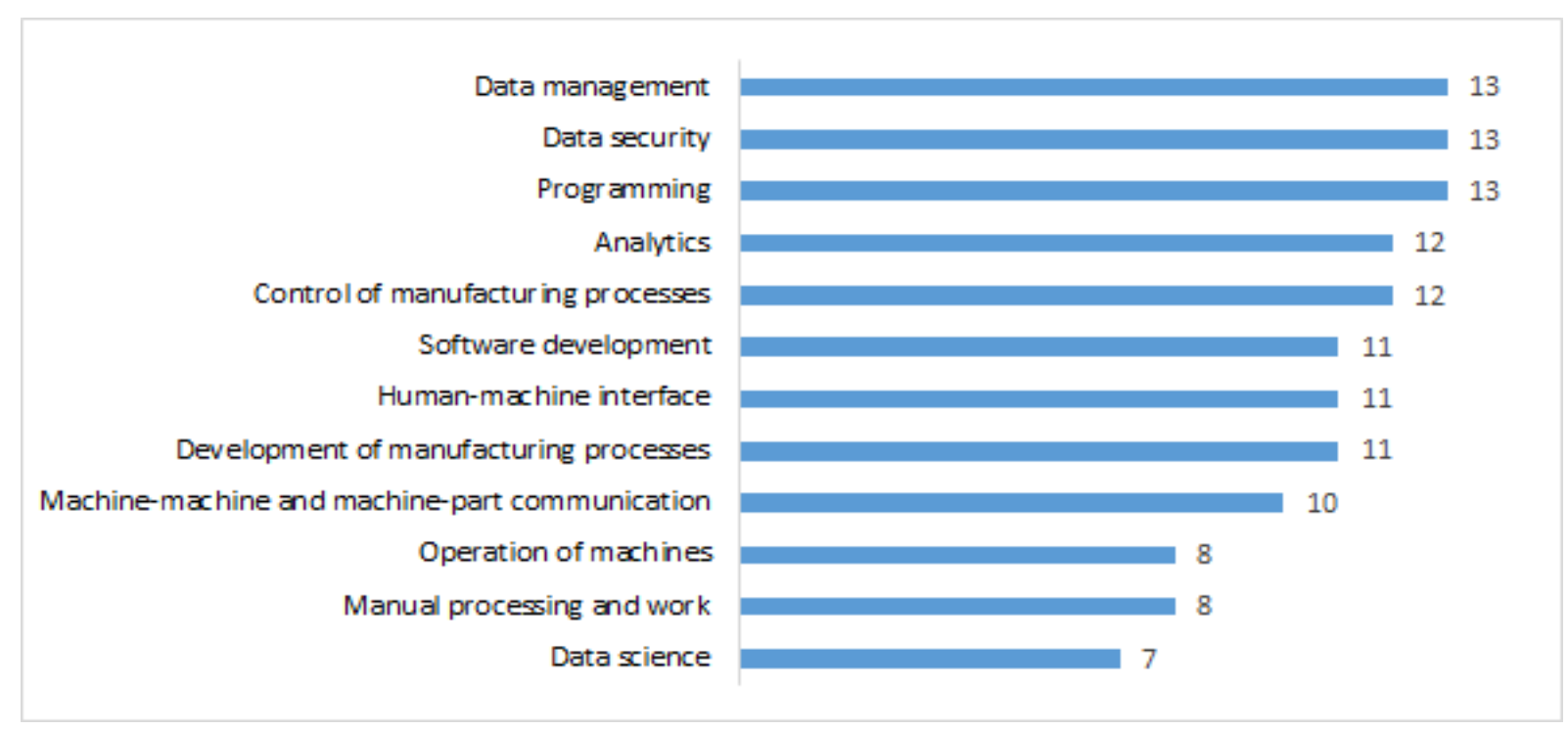

Figure 5: Split of The Responses of The Fourth Question

Companies stated that that they would need qualified employees, especially in data management, data security, programming, analysis, and control of manufacturing processes. 
5) What is the biggest challenge you face in your company in the Industry 4.0 process? (Geissbauer, et al, 2015; Lorenz et al, 2016)

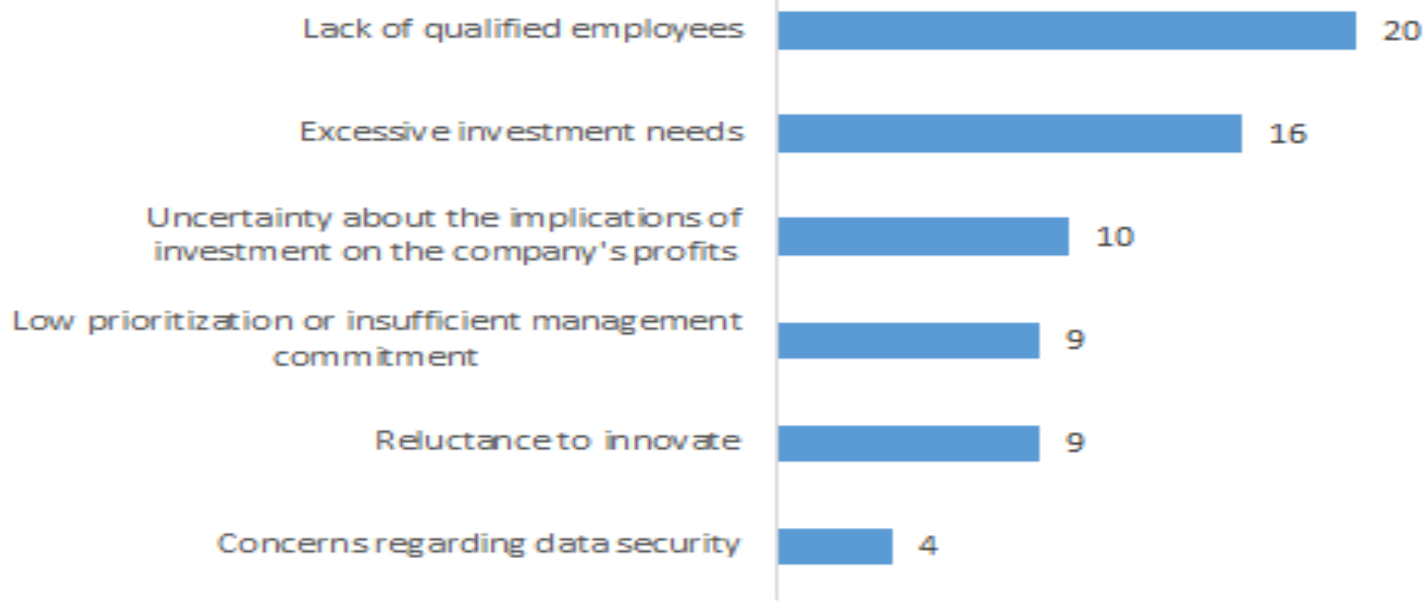

Figure 6: Split of The Responses of The Fifth Question

Firms reported the lack of qualified employees and the need for excessive investment as the greatest challenges to the application of Industry 4.0.

6) What are the benefits of digitalized manufacturing? (Geissbauer, et al, 2015)

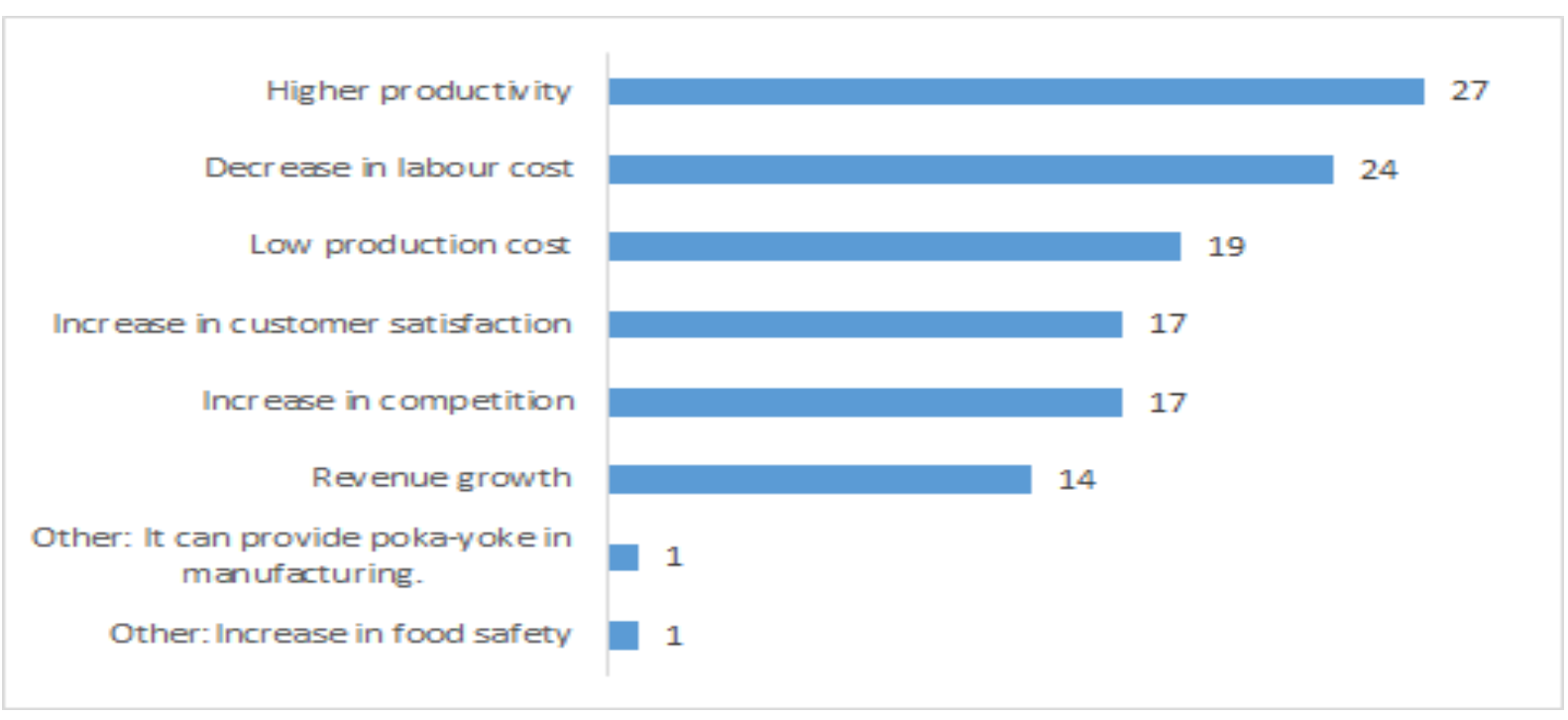

Figure 7: Split of The Responses of The Sixth Question

Firms reported that low production cost, income increases, high productivity, increases in customer satisfaction, increases in competition, increases in food security, and decreases in 
labor cost would comprise the benefits of digital manufacturing. Additionally, one respondent stated that poka-yoke, which means error prevention, should also be provided in manufacturing.

7) Do you think that Industry 4.0 technologies can increase employment problems, because they reduce labor-intensive production?

$$
\text { ves }
$$

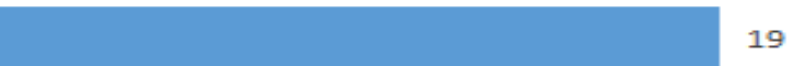

Figure 8: Split of The Responses of The Ninth Question

$58 \%$ of firms stated that Industry 4.0 technologies would cause problems related to unemployment as they reduced labor-intensive production.

8) Do you think that Industry 4.0 technologies can have a positive impact on issues related to society, such as environment and health?

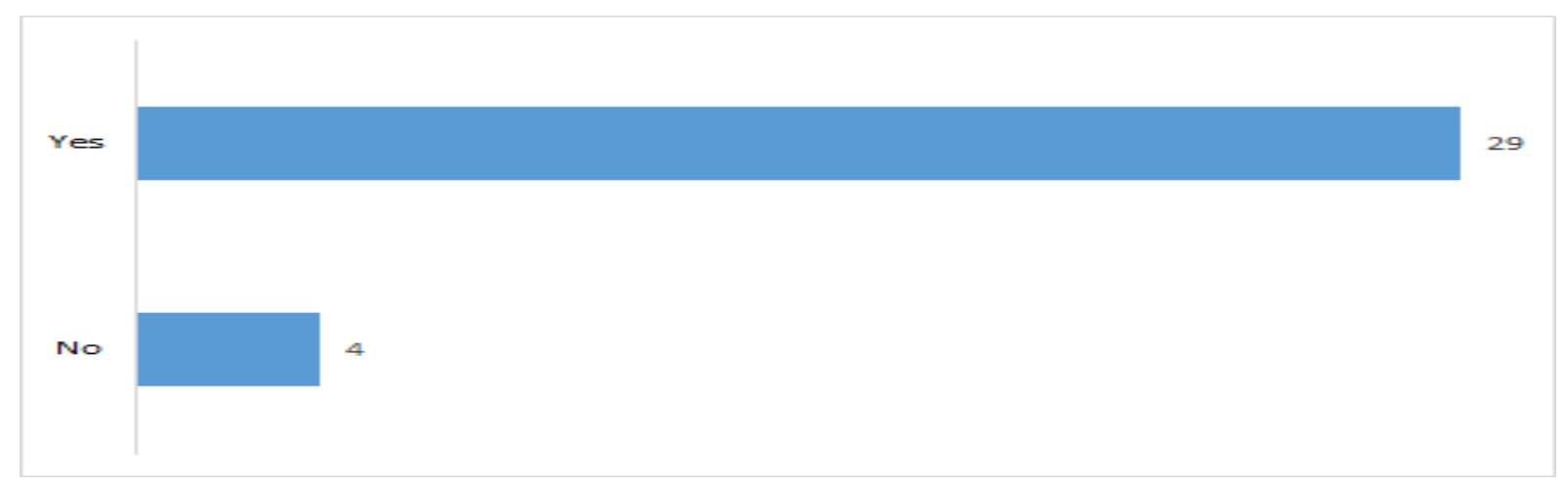

Figure 9: Split of The Responses of The Tenth Question

Most companies asserted that Industry 4.0 would positively impact social issues, such as the environment and health. 


\section{RESULTS and SUGGESTIONS}

In this study, it is strived to determine the effects of Industry 4.0, which has attracted much attention since its introduction to the world; specifically, it is focused on Turkish firms operating in the manufacturing sector. Additionally, issues stemming from the 4th Industrial Revolution (i.e Industry 4.0), are presented.

It is sought to measure firms' levels of awareness and the perceived difficulties faced when adapting to Industry 4.0. The lack of qualified employees and the need for heavy investment were perceived as the major challenges. Companies anticipate a need for qualified personnel to control data management, data security, programming, analysis, and manufacturing processes. Moreover, they foresee that digitalization of production will have benefits, including low production costs, increased revenue, high productivity, increased customer satisfaction, increased competition, better food security, and decreases in labor cost. It is believed that Industry 4.0 technologies will cause problems related to unemployment, because it decreases labor-intensive production needs. However, most firms agreed that these technologies would have an overall positive effect on society.

Society 5.0 is a philosophy that defines the objectives and requirements of the use of the technologies introduced by Industry 4.0. It is not enough for countries to accept Industry 4.0 and make technological innovations/changes so that they do not fall behind in the new age. Countries that have implemented Industry 4.0 should also adopt the philosophy of Society 5.0, because every development focuses on people and society stands to benefit.

After analyzing the survey results, it is noted that most companies had knowledge of Industry 4.0, but many were doubtful about investment, owing to the high investment costs and lack of preparation thus far. Regarding the threat to labor via unemployment, Turkey can overcome this threat by making identified changes per a roadmap, making it possible for the younger population to take a leading role. Senior executives were cognizant of these issues, meaning that Turkey may not be left behind. The problems can be overcome by leveraging opportunities, beginning with adequate government incentives and market preparation. Thus, the general situation of Industry 4.0 in Turkey is promising. 


\section{REFERENCES}

Altınpulluk, H., \& Kesim, M. (2015). Geçmişten günümüze artırılmış gerçeklik uygulamalarında gerçekleşen paradigma değişimleri. Akademik Bilişim Kongresi, 4-6.

Anderl, R. (2014, October). Industrie 4.0-advanced engineering of smart products and smart production. In Proceedings of International Seminar on High Technology(Vol. 19).

Aybek, H. S. Y. (2017). Üniversite 4.0'a geçiş süreci: kavramsal bir yaklaşım. Açıköğretim Uygulamaları ve Araştırmaları Dergisi, 3(2), 164-176.

Baheti, R., \& Gill, H. (2011). Cyber-physical systems. The impact of control technology, 12(1), 161-166.

Bauer W., Schlund S., Marrenbach D., Ganschar O., (2014). Industrie 4.0 - Volkswirtschaftliches Potenzial für Deutschland, Study commissioned by the German Association for Information Technology, Telecommunications and New Media (BITKOM).

Billinghurst, M., Clark, A., \& Lee, G., (2015). "A survey of augmented reality. Foundations and Trends in Human-Computer Interaction”, 8(2-3), 73-272.

Bishop, M. A., (2005). Introduction to computer security (Vol. 50). Boston: Addison-Wesley.

Brynjolfsson, E., Mcafee,A., (2014). The Second Machine Age: Work, Progress, and Prosperity in a Time of Brilliant Technologies, W.W. Noton Company.

Conner, B. P., Manogharan, G. P., Martof, A. N., Rodomsky, L. M., Rodomsky, C. M., Jordan, D. C., \& Limperos, J. W. (2014). Making sense of 3-D printing: Creating a map of additive manufacturing products and services. Additive Manufacturing, 1, 64-76.

Coşkun, S., Kayıkcı, Y., \& Gençay, E. (2019). Adapting Engineering Education to Industry 4.0 Vision. Technologies, 7(1), 10.

Demir, A., (2018). Endüstri 4.0'dan Eğitim 4.0'a Değişen Eğitim-Öğretim Paradigmalari. Electronic Turkish Studies, 13(15).

Doğan, K., \& ARSLANTEKİN, S. (2016). Büyük Veri: Önemi, Yapısı ve Günümüzdeki Durum. DTCF Dergisi, 56(1).Gantz, J., \& Reinsel, D., 2011. Extracting value from chaos. IDC iview, 1142(2011), 1-12.

Geissbauer R., J. Vedso, S. Schrauf, (2015). "Industry 4.0: Building the digital enterprise", Available: https://www.pwc.com/gx/en/industries/industry-4.0.html.

S1la, G.,(2018). Sanayi 4.0 Yolunda Türkiye. Sosyoekonomi, 26(36), 235-243.

Henkoğlu, T., \& Külcü, Ö. (2013). Bilgi erişim platformu olarak bulut bilişim: Riskler ve hukuksal koşullar üzerine bir inceleme. Bilgi Dünyast, 14(1), 62-86.

Hermann, M., Pentek, T., \& Otto, B. (2016, January). Design principles for industrie 4.0 scenarios. In 2016 49th Hawaii international conference on system sciences (HICSS) (pp. 3928-3937). IEEE.

Hofmann, D., Margull, R., Dittrich, P. G., \& Düntsch, E. (2012). Smartphone green vision at dawn of industry 4.0. In Advanced Materials Research (Vol. 403, pp. 4079-4083). Trans Tech Publications.

Hofmann, D., Margull, R., Dittrich, P. G., \& Düntsch, E. (2012). Smartphone green vision at dawn of industry 4.0. In Advanced Materials Research (Vol. 403, pp. 4079-4083). Trans Tech Publications.

Kagermann, H., Lukas, W. D., \& Wahlster, W. (2011). Industrie 4.0: Mit dem Internet der Dinge auf dem Weg zur 4. industriellen Revolution. VDI nachrichten, 13(1).

Keidanren, (2016). Toward realization of the new economy and society Japan Business Federation.

Koca, K. C. (2018). Sanayi 4.0: Türkiye Açısından Fırsatlar ve Tehditler. Sosyoekonomi, 26(36), 245-252.

Landriscina, F., (2013). Simulation and learning: A model-centered approach. Springer Science \& Business Media.

Lasi, H., Fettke, P., Kemper, H. G., Feld, T., \& Hoffmann, M. (2014). Industry 4.0. Business \& information systems engineering, 6(4), 239-242.

Lee, J. (2013). Industry 4.0 in big data environment. German Harting Magazine, 1(1), 8-10.

Lorenz,M., Küpper, D., M. Rüßmann, A. Heidemann, A. Bause, (2016). “Time to Accelerate in the Race Toward Industry 4.0”, https://www.bcgperspectives.com/content/articles/lean-manufacturing-operations-timeaccelerate-race-toward-industry-4/. 
Lukač, D. (2015, November). The fourth ICT-based industrial revolution" Industry 4.0"-HMI and the case of CAE/CAD innovation with EPLAN P8. In 2015 23rd Telecommunications Forum Telfor (TELFOR) (pp. 835-838). IEEE.

Mattern, F., \& Floerkemeier, C. (2010). From the Internet of Computers to the Internet of Things. In From active data management to event-based systems and more (pp. 242-259). Springer, Berlin, Heidelberg.

Nuroğlu, E., (2018). Sanayide Dijital Dönüşüm Yarişinda Türkiye'nin Diş Ticareti İçin Firsatlar ve Tehditler, 14th International Conference on Knowledge, Economy \& Management.

Perales, D. P., Valero, F. A., \& García, A. B. (2018). Industry 4.0: a classification scheme. In Closing the Gap Between Practice and Research in Industrial Engineering (pp. 343-350). Springer, Cham.

Pfeiffer, S. (2017). The vision of "Industrie 4.0" in the making - a case of future told, tamed, and traded. NanoEthics, 11(1), 107-121.

Pîrvu, B. C., \& Zamfirescu, C. B. (2017, August). Smart factory in the context of 4th industrial revolution: challenges and opportunities for Romania. In IOP Conference Series: Materials Science and Engineering (Vol. 227, No. 1, p. 012094). IOP Publishing.

Qin, J., Liu, Y., \& Grosvenor, R. (2016). A categorical framework of manufacturing for industry 4.0 and beyond. Procedia Cirp, 52, 173-178.

Richert, A., Shehadeh, M., Müller, S., Schröder, S., \& Jeschke, S. (2016, June). Robotic Workmates: Hybrid Human-Robot-Teams in the Industry 4.0. In International Conference on e-Learning (p. 127). Academic Conferences International Limited.

Sener, S., \& Elevlı, B. (2017). Endüstri 4.0'da yeni iş kolları ve yüksek öğrenim. Mühendis Beyinler Dergisi, l(2), 25-37.

Seyrek, İ. H. (2011). Bulut Bilişim: İşletmeler için firsatlar ve zorluklar. Gaziantep University Journal of Social Sciences, 10(2), 701-713.

Stearns, P. N. (2018). The industrial revolution in world history. Routledge.

Stock, T., \& Seliger, G. (2016). Opportunities of sustainable manufacturing in industry 4.0. Procedia Cirp, 40, 536-541.

Soylu, A. (2018). Endüstri 4.0 ve girişimcilikte yeni yaklaşımlar. Pamukkale Üniversitesi Sosyal Bilimler Enstitüsü Dergisi, (32), 43-57.

Wegner, A., Graham, J., \& Ribble, E. (2017). A new approach to cyberphysical security in industry 4.0. In Cybersecurity for Industry 4.0 (pp. 59-72). Springer, Cham.

Zhang, Q., Cheng, L., \& Boutaba, R. (2010). Cloud computing: state-of-the-art and research challenges. Journal of internet services and applications, 1(1), 7-18.

Çelen, S. (2017). Sanayi 4.0 ve Simülasyon. International Journal of 3D Printing Technologies and Digital Industry, 1(1), 9-26.

Öksüz, M. K., Öner, M., \& Öner, S. C. ,(2017). Yalin Üretim Tekniklerinin Endüstri 4.0 Perspektifinden Değerlendirilmesi, Uluslararası Bölgesel Kalkınma Konferansı.

Özkan, M., Al, A., \& Yavuz, S. (2018). Uluslararası Politik Ekonomi Açısından Dördüncü Sanayi-Endüstri Devrimi’nin Etkileri ve Türkiye. International Journal of Political Science \& Urban Studies, 6(2).

Özköse, H., Arı, E. S., \& Gencer, C. (2015). Yesterday, today and tomorrow of big data. Procedia-Social and Behavioral Sciences, 195, 1042-1050.

Öztemel, E. (2018). Eğitimde yeni yönelimlerin değerlendirilmesi ve Eğitim 4.0. Üniversite Araştırmaları Dergisi, 1(1), 25-30.

Ünver, M., \& Özbilgin, İ. G., (2017). Ulusal Nesnelerin İnterneti Stratejisi Önerisi., 4. Uluslararası Yönetim Bilişim Sistemleri Konferansı "Endüstri 4.0" 